\title{
Treg Cells, Life History, and Diversity
}

\author{
Christophe Benoist and Diane Mathis \\ Division of Immunology, Department of Microbiology and Immunobiology, Harvard Medical School, \\ Boston, Massachusetts 02115 \\ Correspondence: cbdm@hms.harvard.edu
}

Regulatory T cells expressing the FoxP3 transcription factor have a profound and nonredundant role in several aspects of immunological tolerance. We will review here the specification of this lineage, its population dynamics, and the diversity of subphenotypes that correlate with their diverse roles in controlling inflammation in a variety of settings.

Sulpting a functional but self-tolerant reper$S$ toire of T cells first involves a broad roughing in the thymus, eliminating immature thymocytes whose T-cell receptor (TCR) responds to self-antigens presented by thymic antigenpresenting cells (APCs). But potentially autoreactive $\mathrm{T}$ cells do escape thymic negative selection, and need to be controlled by peripheral mechanisms of tolerance induction. Self/nonself discrimination poses an inherent challenge in peripheral lymphoid organs that are open to environmental antigens, and relies in part on cues from differential presentation (timing, dose, or costimulatory environment) as discussed in Xing and Hogquist (2012). Peripheral tolerance also includes dominant mechanisms, wherein particular cells exert an inhibitory influence on the activation or effector function of other cell types. Such suppressive, or apparently suppressive, effects can stem from the normal balance between effector functions that tend to inhibit each other, such as the mutual antagonism between Th1 and Th2 effectors; at some level, every cell type probably inhibits some other, without implying any particularly "suppressive" function. But the immunological constellation also includes cells whose primordial role seems to be the dominant control of other cells, at least as currently perceived. The only truly well characterized of these "regulatory" cells are FoxP3 ${ }^{+} \mathrm{CD}^{+}{ }^{+} \mathrm{T}$ cells (Tregs), the topic of much scrutiny over the last decade. As a result, we have a broad perspective on these cells, which affect many facets of immune tolerance: to unperturbed self, to infected or tumoral self, to artificial or natural (e.g., pregnancy) grafts. Indeed, their scope also extends beyond immune tolerance, more generally to controlling a variety of inflammatory processes. As their cellular determinism and function have been extensively reviewed over the past few years (Brusko et al. 2008; Sakaguchi et al. 2008; Vignali et al. 2008; Belkaid and Tarbell 2009; Feuerer et al. 2009b; Littman and Rudensky 2010, 2011), we will present a more focused discussion of the origin, fate, and diversity of Tregs, in relation to their basic physiology and to pathological implications.

Editors: Diane Mathis and Alexander Y. Rudensky

Additional Perspectives on Immune Tolerance available at www.cshperspectives.org

Copyright (C) 2012 Cold Spring Harbor Laboratory Press; all rights reserved; doi: 10.1101/cshperspect.a007021

Cite this article as Cold Spring Harb Perspect Biol 2012;4:a007021 


\section{FoxP3 ${ }^{+}$Treg IDENTITY: A SHORT OVERVIEW}

Treg cells were identified as $\mathrm{CD} 4^{+} \mathrm{T}$ cells expressing high levels of CD25 or low levels of $\mathrm{CD} 45 \mathrm{RB}$, and able to protect from autoimmune pathology induced by neonatal thymectomy or by reconstitution of lymphopenic rodents (Sakaguchi et al. 1982, 1995; Powrie and Mason 1990; Smith et al. 1991; Morrissey et al. 1993; Suri-Payer et al. 1998). The lack of specificity of these markers, shared with activated T cells, and the contrived nature of the experimental settings, initially led to skepticism as to their true relevance to immune tolerance. This skepticism was enhanced by the bitter aftertaste left by the embarrassing collapse of the "suppressor cells" house of cards in the early 1980s (Germain 2008). The breakthrough that led to general acceptance of Treg cells as a distinct phenotype/ lineage was the identification of the transcription factor FoxP3 (Chatila et al. 2000; Brunkow et al. 2001; Wildin et al. 2001), and of its unique expression in Treg cells (Fontenot et al. 2003, 2005b; Hori et al. 2003; Khattri et al. 2003; Wan and Flavell 2005). Deficiencies in Foxp3 were shown to cause lymphoproliferation and multiorgan autoimmunity in scurfy mutant mice and human IPEX patients (Ziegler 2006). This pathology could be rescued by transfer of Treg cells (Fontenot et al. 2003), and was reproduced by inactivation of FoxP3 uniquely in $\mathrm{T}$ cells (Fontenot et al. 2005b), proving the T-cellautonomous role of FoxP3. Aside from providing a unique molecular identifier, these results established that Tregs were not merely constructions from contrived and artifact-prone experimental systems in mice, but actually played a nonredundant role in immune tolerance and homeostasis.

FoxP $3^{+}$Treg cells use the $\alpha \beta$ TCR for antigen recognition, and have a broad repertoire, comparable in size to, but largely distinct in composition from, that of conventional $\mathrm{CD}^{+} \mathrm{T}$ cells (Tconv) (Hsieh et al. 2006; Pacholczyk et al. 2006; Wong et al. 2007b; Lathrop et al. 2008). Consistent with their expression of $\mathrm{CD} 4$, they are restricted by MHC-II molecules, although some MHC-I-restricted $\mathrm{CD}_{8}^{+}$or $\mathrm{CD} 4^{+} \mathrm{CD}^{+}$
FoxP $^{+}$cells are observed in MHC-II-deficient mice (Krajina et al. 2004; Bienvenu et al. 2005; Fontenot et al. 2005b; Stephens et al. 2007) and in anti-CD3-treated human patients (Bisikirska et al. 2005).

Treg cells were long thought to represent an anergic phenotype, because they are largely unresponsive to the usual TCR triggers in vitro. Indeed, this nonresponsiveness extends dominantly to Tconv cells cultured together with Tregs, forming the basis for the classic in vitro suppression assay (Takahashi et al. 1998; Thornton and Shevach 1998). On the other hand, it is now recognized that this apparent anergy is really an in vitro artifact and that Treg cells are far from anergic in vivo. Indeed, Tregs actually cycle more actively than Tconv, spontaneously or in response to specific antigen (Fisson et al. 2003; Walker et al. 2003; Kretschmer et al. 2005). The anergic in vitro phenotype likely reflects the very strong dependence of Treg cells on IL2, which they are unable to synthesize but which is key to their differentiation, homeostasis, and function (Furtado et al. 2002; Malek et al. 2002; Bensinger et al. 2004; Thornton et al. 2004; Fontenot et al. 2005a; Setoguchi et al. 2005; Tai et al. 2005; Lio and Hsieh 2008; Yu et al. 2009). This dependence of Treg cells on the IL2 produced by Tconv cells provides a negative-feedback loop in which the amplification of Tregs is directly conditioned by the degree of Tconv activation. Treg cells are under strong homeostatic control. Their numbers recover within a day or two in lineage ablation experiments (Kim et al. 2007; Feuerer et al. 2009c), and they rapidly fill empty niches after transfer into lymphopenic conditions or after systemic perturbation by anti-CD3 (Nishio et al. 2010).

\section{FoxP3 ${ }^{+}$Treg CELLS: DIFFERENTIATION}

Two origins have been described for $\mathrm{FoxP}^{+}$ cells, whose numeric and functional importance remain in question. Most FoxP ${ }^{+}$cells differentiate in the thymus from immature $\mathrm{CD} 4^{+} \mathrm{CD} 8^{+}$ precursors, as an alternative to conventional $\mathrm{CD} 4{ }^{+} \mathrm{T}$ cells. The second occurs in the periphery, where a number of triggers induce the expression of FoxP3 in Tconv cells. The former are 
commonly referred to as "natural" or "thymusderived" (here tTregs), the latter as "induced, adaptive, peripheral" (in view of the semantic inadequacy of the former terms, we will refer to these as pTreg).

In experimental conditions, the Foxp $3^{+}$ pTreg phenotype results from in vivo "conversion" of mature Foxp $3^{-} \mathrm{CD} 4^{+}$cells in a variety of conditions: chronic and/or suboptimal stimulation by agonist peptide, exposure to agonist administered orally, response to homeostatic cues after transfer into lymphopenic hosts, or in response to helminth infection (Apostolou and von Boehmer 2004; Kretschmer et al. 2005; Finney et al. 2007; Curotto de Lafaille et al. 2008; McSorley et al. 2008; Haribhai et al. 2009, 2011; Daniel et al. 2010; Feuerer et al. 2010; Grainger et al. 2010). In addition, natural antigens from commensal bacteria can elicit particular populations of Foxp $3^{+}$Tregs specifically in the colon (Atarashi et al. 2010; Lathrop et al. 2011). The construction of transgenic mice expressing TCRs isolated from these microbe-responsive pTregs showed that these TCRs cannot entice Treg selection in the thymus, implying that many colonic Tregs arise from antigen-driven pTreg development (Lathrop et al. 2011). Peripherally generated $\mathrm{p}$ Tregs proved as effective as bulk Tregs in several functional assays. Indeed, the conditions that promote their conversion can lead to superior suppressive ability, in part by ensuring an antigen-specific repertoire (Daniel et al. 2010; Haribhai et al. 2011). pTregs are also largely similar to bulk Tregs from lymphoid organs in regard to their transcriptional signatures, although there are some fine differences that reflect their mode of conversion (e.g., antigen- vs. homeostatic-driven conversion [Haribhai et al. 2009; Feuerer et al. 2010]).

Perhaps with the exception of the colonic Treg mentioned above, the true contribution of pTregs to the Treg pools and function remains incompletely defined. There has been much enthusiasm to extrapolate from in vitro results, to consider that any local expansion of Treg cells represents a conversion event, and generally that pTregs are a branch of T-cell differentiation akin to Th1/2/17 fates (Curotto de Lafaille et al. 2008). Yet, only in a few instances has the in vivo relevance of pTregs been tested with transfers of rigorously purified Tconv cells, a test essential to distinguish true pTreg generation from the expansion of preexisting tTregs. The lack of specific molecular identifiers of pTregs has also been a confounder. It was suggested that expression of the transcription factor Helios ( Ikzf2) might serve as a marker of thymus-derived Tregs (Thornton et al. 2010). Unfortunately, it is now realized that Helios is expressed at substantial levels in pTregs induced peripherally by lymphopenia or agonist peptide (Verhagen and Wraith 2010; Darce et al. 2012; Gottschalk et al. 2012) and is generically induced upon activation of $\mathrm{CD} 4^{+} \mathrm{T}$ cells (Akimova et al. 2011; Serre et al. 2011). Analyses of TCR repertoires in unchallenged mice have shown a high degree of similarity between Tregs in the thymus and peripheral lymphoid organs (Hsieh et al. 2006; Pacholczyk et al. 2006; Wong et al. 2007b), suggesting that tTregs constitute the majority of those pools (there is admittedly a caveat to this argument, which assumes that there is little or no colonization of thymic pools by recirculation from the periphery). Similar observations were made in the context of autoimmune lesions, in which Tregs seem to mainly result from recruitment and amplification of preexisting tTregs, rather than from local conversion (Korn et al. 2007; Wong et al. 2007a; Liu et al. 2009). It will be important, in responses to infection or tumors, to obtain a better understanding of the relative contribution of the expansion of preexisting tTregs relative to de novo pTreg generation. It has been suggested that tTregs and pTregs may come into play at different times of Toxoplasma gondii lesions, pTregs perhaps becoming important in later stages, after initial control by preexisting Tregs (R Maizels, pers. comm.); on the other hand, the high prevalence of Tregs in chronic Leishmania cutaneous lesions seems solely attributable to tTregs (Suffia et al. 2006). A mutant mouse bearing a deletion in the CNS1 enhancer region of the Foxp3 locus necessary for peripheral induction showed localized Th2-driven pathologies at mucosal sites, rather than the generalized autoimmunity of fully Treg-deficient animals, indicating that pTregs may preferentially come into 
play at mucosal interfaces. In a further application of pTregs at organismal boundaries, it has recently been suggested that $\mathrm{pTregs}$ have an elective function at the foeto-maternal interface (Samstein et al. 2012).

Besides in vivo-generated pTregs, Foxp $3^{+}$ cells can be very easily induced in vitro by TCRmediated activation of naïve $\mathrm{T}$ cells in the presence of TGF $\beta$ and IL2 ("TGF-Treg") (Chen et al. 2003; Fantini et al. 2004; Peng et al. 2004). There has been a tendency to generalize from these results to Treg physiology in vivo, and to assume that TGF $\beta$ is an important driver of Treg differentiation, which would preferentially occur in locales with higher TGF $\beta$ levels. Yet, the functionality and relevance of these in vitro-generated Foxp $3^{+}$cells have been questioned. Although Foxp3 expression is high in TGF-Tregs it is very unstable because of, or reflected by, incomplete $\mathrm{CpG}$ demethylation at the Foxp3 locus (Floess et al. 2007; Huehn et al. 2009). Perhaps not surprisingly given this instability, their functional ability has proven variable (Chen et al. 2003; Davidson et al. 2007; Floess et al. 2007; Hill et al. 2007; Aricha et al. 2008; Huter et al. 2008), although some of this variability may have reflected genetic differences between inbred strains (D'Alise et al. 2011). Deletion of a conserved enhancer motif in Foxp3 that is needed for response to TGF $\beta$ results in only modest effects on Treg numbers in vivo (mainly as a partial reduction of Treg numbers in the gut) (Zheng et al. 2010 ), and TGF $\beta$ proved unnecessary for thymic Treg differentiation, except in the neonatal period (Liu et al. 2008). Retinoic acid also enhances the activation of the Foxp3 locus in vitro (Benson et al. 2007; Coombes et al. 2007; Mucida et al. 2007; Sun et al. 2007; Elias et al. 2008), perhaps through direct enhancement or indirectly by curtailing inhibitory cytokines (Hill et al. 2008; Nolting et al. 2009), although in vivo effects are far more complex owing to retinoic acid's pleiotropic effects on many cell types, including effector cells (Hall et al. 2011).

In the thymus, maturing $\mathrm{T}$ cells at the double-positive (DP) and single-positive (SP) stages are selected into the Treg lineage, as an alternative to Tconv fate, as one of the "clonal deviation" escape pathways together with NKT cells or
CD8 $\alpha \alpha$ IEL precursors. Treg selection requires TCR:MHC (major histocompatibility complex) molecular interactions, as evidenced by their reduction in MHC-deficient mice (Krajina et al. 2004; Bienvenu et al. 2005; Fontenot et al. 2005b; Stephens et al. 2007), but also requires costimulatory signals from CD28, which seems to amplify the probability that cells expressing a TCR committing them to Treg fate are actually selected (Salomon et al. 2000; Tai et al. 2005; Lio et al. 2010). Treg differentiation follows a two-step process, through a FoxP3-negative CD25 ${ }^{\text {hi }}$ intermediate that secondarily converts to FoxP3 ${ }^{\text {hi }}$ under the influence of trophic cytokines, in particular, IL2 (Burchill et al. 2008; Lio and Hsieh 2008). Engagement of the TCR by agonist ligands strongly favors the selection of Treg cells, either by inducing differentiation along the lineage (Jordan et al. 2001; Apostolou et al. 2002; Kawahata et al. 2002; Walker et al. 2003), or because FoxP $3^{+}$cells are inherently more resistant to clonal deletion (Liston et al. 2003; Van Santen et al. 2004; Bonasio et al. 2006), or both. It would be an oversimplification, however, to conclude that all Treg cells are necessarily self-reactive ( $\mathrm{Pa}$ cholczyk et al. 2007; Dipaolo and Shevach 2009), if only because "self-reactivity" is a relative concept, highly influenced by the mode of self-antigen presentation and the state of the responding cell. Indeed, repertoire analyses show that a significant proportion of TCR sequences are used by both Treg and Tconv cells (Hsieh et al. 2006; Pacholczyk et al. 2006; Wong et al. 2007b), indicating that a number of Treg cells are no more self-reactive than are Tconv cells.

In addition, recent work has shown a very strong degree of intraclonal competition between Treg cells expressing the same or related TCRs, which greatly limits the probability of similar Tregs to differentiate in concert (Bautista et al. 2009; Leung et al. 2009). This observation explains the long-standing riddle of the quasi-absence of Treg cells in TCR transgenic mice on a RAG-deficient background. These niche limitations may stem from strict competition for limiting ligands, or perhaps from the propensity of Tregs to suppress other cells in their vicinity, which might include other Tregs as well. Interestingly, strong control on niche 
size for thymic selection also seems to apply for peripheral homeostasis (Nishio et al. 2010).

In an oft-repeated but largely unsupported assertion, Treg differentiation is presented as occurring in a window of affinity of TCR engagement by MHC molecules, higher than that required for positive selection of Tconv cells, but lower than that inducing clonal deletion. Results in support of this observation have only recently come from the analysis of a Nurr77-GFP reporter whose expression correlates with the strength of the TCR signal: the reporter was consistently expressed at a higher level in Tregs than in conventional CD4 ${ }^{+} \mathrm{T}$ cells (Moran et al. 2011). Contradicting this simple model, however, are studies in which a low-affinity agonist variant that remained active in negative selection was unable to enhance Treg differentiation (Cozzo et al. 2011), an observation incompatible with a straightforward "window of affinity" interpretation. Rather, commitment to the Treg lineage may reflect a particular balance and intensity of TCR signals different from that eliciting apoptosis or Tconv differentiation. Activation of the NF- $\kappa B$ pathway leading to $c$-Rel seems particularly important for Treg cell differentiation, more so than for Tconv cells, because deficits in several elements that connect the TCR to NF- $\kappa B$ perferentially curtail Treg differentiation. Defective Treg cell selection is observed in knockouts of PKC $\theta$, BCL10, CARMA1 TAK1, IKK2, and cREL (Schmidt-Supprian et al. 2003, 2004; Sato et al. 2006; Wan et al. 2006; Barnes et al. 2009; Long et al. 2009; Medoff et al. 2009; Ruan et al. 2009). The level of NF$\kappa \mathrm{B}$ activation in the thymus correlates with FoxP3 induction, and Treg differentiation in TAK1 - or CARMA1-deficient mice can be rescued by transgenic expression of a constitutively active IKK2 (Long et al. 2009). The presence of a cREL binding site in the CNS3 segment of the first intron of Foxp3 may provide a landing point for this axis (Zheng et al. 2010), but it is also conceivable that NF- $\kappa \mathrm{B}$ promotes Treg differentiation by modulating other TFs, such as Hifl $\alpha$.

Opposing this positive influence of the NF$\kappa \mathrm{B}$ pathway, signaling through the AKT pathway dampens thymic and peripheral Treg differ- entiation. Constitutively active Akt impairs thymic differentiation of Treg cells as well as their induction by TGF $\beta$ (Haxhinasto et al. 2008; Sauer et al. 2008), consistent with a positive effect of rapamycin on Treg cell selection and expansion (Zheng et al. 2003; Battaglia et al. 2005; Qu et al. 2007; Strauss et al. 2007; Haxhinasto et al. 2008; Sauer et al. 2008). This activity was attributed to the mTORC2 complex (Delgoffe et al. 2011), and may proceed through inactivation of Foxo1/3, which are needed for optimal FoxP3 induction (Kerdiles et al. 2010; Ouyang et al. 2010). This negative impact of the PI3K/Akt pathway may also stem from activation of cell metabolism. Concordant with this view, Hifl $\alpha$ has recently been suggested to promote Th17 differentiation and to counterregulate Tregs by targeting FoxP3 for degradation, and perhaps also by favoring active metabolic conditions in the cell that are more favorable to Tconv expansion (Dang et al. 2011; Shi et al. 2011). Similarly, NR4a1 (a.k.a. Nur77), part of the immediate-early response to cell activation, also antagonizes Treg selection, again in the context of transcriptional activation of glycolytic pathways (Fassett et al. 2012). Thus, one might speculate that selection into the Treg cell lineage depends not so much on absolute strength of TCR signals as on the relative balance of NF- $\kappa \mathrm{B}$ and of metabolic activation. The Treg phenotype might be favored by activation in a context of relative starvation of the differentiating cell. Such a view would also be consistent with the notion of peripheral induction of pTregs by suboptimal presentation in the absence of costimulatory signals, which also favor full metabolic activity. (In contrast, the requirement for CD28 during Treg selection in the thymus, which involves both a trans dependence on costimulation for the production of IL2 and a cell-autonomous cis requirement in Treg precursors [Tai et al. 2005], may reflect the need to amplify weaker TCR signals.)

\section{FOREVER Tregs?}

Phenotypic stability is an important consideration for Treg cells. The self-reactivity of the TCR expressed by many of them makes it 
important for their suppressive phenotype to be stable and maintain the expression of FoxP3 and the suppressor pathways it controls, lest they convert into aggressive effectors. Indeed, one hypothesis proposed that much of the pool of autoreactive T cells in autoimmune disease may consist of "ex-Treg" cells that turned rogue after losing FoxP3 expression (Zhou et al. 2009; Bailey-Bucktrout and Bluestone 2011). Initial support for Treg instability stemmed from transfer of congenically marked Treg cells into alymphoid hosts, which resulted in sizable FoxP3-negative populations (Duarte et al. 2009; Tsuji et al. 2009). These experiments carried the caveat of the artificial drive of the lymphopenic environment, and/or of homeostatically driven expansion of small numbers of contaminating Tconv cells in the inoculum. This was a particular concern because such results only concerned a fraction of FoxP ${ }^{+}$cells (Komatsu et al. 2009), and were not observed after transfers into normal hosts, even in the context of a strong autoimmune disease (Rubtsov et al. 2010). Lineage tracing experiments based on Foxp3-cre transgenes then showed that many cells in the $\mathrm{CD}^{+}$effector/memory pools had, at some point in their life history, activated the FoxP3 locus (Zhou et al. 2009). There was a pitfall to these experiments, however, in that the tracer system was continuously active, and would tag cells with a transiently active Foxp3 locus. Indeed, when similar lineage tracing experiments were performed in pulse-chase mode with a Tamoxifen-controlled Foxp3-creERT transgene that tagged FoxP3-expressing cells only during a defined time frame, the Treg phenotype of their progeny was found to be extremely stable over time, even in conditions of ongoing inflammation (perhaps with the exception of IL2 quenching) (Rubtsovet al. 2010). Thus, the large number of labeled effector/memory cells in the initial experiments likely reflected the accumulation over time of Teff cells that transiently expressed FoxP3 at the onset of activation, as has been well documented in human $\mathrm{CD} 4^{+}$ cells. This interpretation was recently confirmed independently (Miyao et al. 2012). This transient activation of the Foxp3 locus also implies that results from conditional knockout experi- ments that use Foxp3-cre should be interpreted with some caution, particularly when a strong drive may affect the population dynamics of cells bearing the genetic excision. Although the vast majority of Tregs likely remain Tregs (at least over the lifetime of a mouse), it is probably worth keeping in mind that Tregs can lose FoxP3 and suppressive activity when mistreated (e.g., local IL2 deprivation). This possibility needs to be taken into account when devising therapies based on Treg transfer (Brusko et al. 2008).

\section{DETERMINANTS OF Treg FUNCTION IN VIVO}

Several elements condition the functional ability of Treg cells to perform their inhibitory functions:

1. Specificity. The overall TCR repertoire of Tregs is essentially as diverse as that of Tconv cells, and both have the same capacity for broad recognition of the antigenic universe. This TCR specificity is essential in directing Treg inhibitory activity, via direct killing of B or dendritic cells (DCs) that present the cognate antigen, or via bystander suppression of neighboring $\mathrm{T}$ cells responding to the same antigen source. As for other Tor B lymphocytes, antigen-specific receptors expressed by Tregs can drive clonal expansion in response to exogenous antigens (Nishimura et al. 2004; Suffia et al. 2006). Treg suppression does not require matching epitopes on the T cells it suppresses, however, as shown in vitro (Takahashi et al. 2000) or by the dominant protection of a polyclonal autoimmune infiltrate afforded by monospecific Tregs (Tang et al. 2004; Tarbell et al. 2004; Chen et al. 2005). This focusing of Treg action is essential, however, and Tregs displaying a TCR specific for a particular self-antigen are far more effective at inhibiting the relevant autoimmune destruction than are polyclonal populations (Tang et al. 2004; Tarbell et al. 2004).

2. Location is essential for Tregs to control antimicrobial or autoimmune responses. In 
theory, Tregs could affect the generation of effector lymphocytes at several different points of their activation process: during the initial priming and differentiation in draining lymph nodes, during their migration to target organs, or at sites of tissular inflammation. Arguments have been presented for an effect on initial activation (Tang et al. 2006), cellular migration (Sarween et al. 2004; Davidson and Shevach 2011), or the control of terminal inflammation in the target organ (Chen et al. 2005; Suffia et al. 2006; Feuerer et al. 2009c). Indeed, Tregs establish a local balance with autoreactive cells, or a three-way balance with the infecting agent and the inflammatory response, which results in limitation of both immunopathology and damage by the infectious agent. TCR specificity can contribute to this homing to inflammatory locales, helping to attract and/or retain specific Tregs. Receptor specificity is complemented by an array of chemokine receptors on Tregs (Siegmund et al. 2005; Wei et al. 2006), and different Treg subpopulations express a range of chemokine receptors (Feuerer et al. 2010) that promote their differential tissue localization. For instance, CCL28 secreted by hypoxic tumors recruits CCR10 ${ }^{+}$Tregs (Facciabene et al. 2011), CXCR5 is expressed by Tregs that control germinal center (GC) B cells (Linterman et al.2011), and CCR9 ${ }^{+}$and/or CX3CR1 are required for Treg cells to home and expand in the gut lamina propria (Menning et al. 2010; Hadis et al. 2011).

3. Effector strategies. A broad array of molecular mechanisms is used by Tregs, which involve molecules that are typical members of the Treg signature: release of inhibitory cytokines (TGFß, IL-10, IL-35) and their carriers (Lrrc32, a.k.a. GARP), deprivation of trophic cytokines (in particular, IL2 via expression of the high-affinity IL2R $\alpha$ ), direct killing of dendritic cells (GrnzA/B), suppression of DC maturation (LAG-3), stripping of costimulatory ligands from APCs (CTLA-4), CAMP- or adenosine-mediated inhibition (CD39, CD73), and amino acid deprivation through induction of indoleamine 2,3-dioxygenase in DCs (Vignali et al. 2008; Shevach 2009). This diversity is probably linked to the range of cellular targets, which include cells of the innate immune system (dendritic cells, natural killer [NK] cells) as well as adaptive Tor B lymphocytes. It also raises the possibility that Treg defects that partake in the determinism of autoimmune disease might be focalized, affecting only a facet of Treg function, rather than a generalized reduction in Treg numbers or activity. A specific defect in Treg activity via CD39 has been suggested to contribute to multiple sclerosis (Fletcher et al. 2009). Such focalized defects might not be apparent when assessing Treg function through tests that may primarily reflect another of these suppressive pathways.

\section{FoxP3 ${ }^{+}$Treg CELLS: DIVERSITY}

Correspondingly, a number of Treg subphenotypes have been delineated, with differential effector functions and tissue localization (reviewed in Feuerer et al. 2009b). There is really no such thing as a generic Treg cell. Indeed, Treg cells can even secrete proinflammatory cytokines such as IFN $\gamma$ or IL-17 in contexts of microbial or parasitic challenge (Oldenhove et al. 2009), and it will probably be recognized that, in some instances, FoxP $3^{+}$Tregs can actually have effector rather than suppressive function.

In addition, different facets of Treg cells are brought to bear to control specialized Th effector functions. Interestingly, these programs appear to be determined in Treg cells by the same transcription factors that are central to the differentiated functions of the Tconv cells they regulate. For instance, Irf4 is required for the differentiation of B cells and of the Th2/17-type cells that help them, and the absence of Irf4 in Tregs impairs their ability to limit Th2 responses and antibody production (Zheng et al. 2009). Similarly, Treg cells expressing Tbet or STAT3 optimally suppress inflammatory Th1 and Th17 responses (Chaudhry et al. 2009; Koch et al. 2009). Treg cells can also use the Bcl6-directed transcriptional module (including Cxcr5 or PD1) that controls entry into 
GCs, where they limit the number of B cells, favoring the selective expansion of antigen-specific B cells (Linterman et al. 2011).

These alternative effector functions have direct relevance to pathology, as illustrated by a FoxP3 mutant mouse that is highly resistant to Th2/17-dependent arthritis, but at the price of increased susceptibility to Th1-dependent diabetes (Bettini et al. 2012; Darce et al. 2012). Some of these target-specific functions, such as those of GC or adipose tissue Tregs discussed below, correspond to distinct cell phenotypes, which include chemokine receptors needed to migrate to and reside in those locations, together with effector molecules needed there. But others are ubiquitously expressed pathways shared by all Tregs: the expression of Irf4 and the preferential suppression of Th2/17 that it controls appear broadly distributed among Tregs.

In addition, it is important not to merely consider Tregs as obtuse suppressors of any form of activity in other immune cells. Indeed, Tregs can contribute positively to the specificity and efficacy of immune responses. Acute Treg lineage ablation leads to more aggressive genital herpes infection, with insufficient interferon production and NK recruitment in the infected tissue, owing to a florid but ultimately unhelpful response that takes place in the draining lymph node (Lund et al. 2008). They can enhance the affinity maturation of the antibody response (Linterman et al. 2011). Paradoxically, given the common perception that Treg and Th17 cells represent balanced forks of differentiation, in some settings Tregs actually promote acute Th17 responses to antigen, likely by preventing the inhibitory effects of IL2 (Chen et al. 2011).

Even further from Treg's home base of immune tolerance are the FoxP $3^{+}$cells found in nonlymphoid settings of inflammation, such as the atherosclerotic plaque (Ait-Oufella et al. 2006) or "fat Tregs" that colonize the visceral adipose tissue (Feuerer et al. 2009a). Although bona fide Tregs judging by their phenotype and transcription profiles, they also express distinct transcripts that reflect homing and adaptation to the adipose tissue. In a new role, these Tregs influence metabolic parameters such as insulin resistance by dampening inflammation in the adipose tissue. Other extralymphoid Treg populations may yet to be discovered, a common theme being perhaps an attraction of Treg cells for settings with NF- $\kappa \mathrm{B}$ activation, found in infected locales, as well as sterile inflammation such as encountered in the adipose tissue.

A unifying perspective may be that the overall physiological function of Tregs is not really to maintain immune tolerance, but more generally to ensure tissue homeostasis (where "tissue" includes the commensal microbial self) and to bring inflammation to proper resolution. Such a definition would account well for the control exerted by Tregs on numbers and activity of T, B, $\mathrm{NK}$, or adipose macrophages. In the same vein, the syndromes that develop in scurfy mice and IPEX patients are perhaps due to unconstrained homeostasis and inflammation, rather than to autoimmunity through lack of tolerance.

\section{ACKNOWLEDGMENTS}

We apologize to our colleagues for the many articles that could not be quoted because of space limitations. We thank Drs. V. Kuchroo, R. Maizels, A. Rudensky, and D. Vignali for enlightening discussions. Work in the authors' laboratory on this topic is supported by grants RO1-AI51530 from NIH/NIAID, R01DK92541 from NIH/NIDDK, 4-2007-1057 from the JDRF, and GlaxoSmithKline.

\section{REFERENCES}

${ }^{*}$ Reference is also in this collection.

Ait-Oufella H, Salomon BL, Potteaux S, Robertson AK, Gourdy P, Zoll J, Merval R, Esposito B, Cohen JL, Fisson S, et al. 2006. Natural regulatory T cells control the development of atherosclerosis in mice. Nat Med 12: 178180.

Akimova T, Beier UH, Wang L, Levine MH, Hancock WW. 2011. Helios expression is a marker of $\mathrm{T}$ cell activation and proliferation. PLOS ONE 6: e24226.

Apostolou I, von Boehmer H. 2004. In vivo instruction of suppressor commitment in naive T cells. J Exp Med 199: 1401-1408.

Apostolou I, Sarukhan A, Klein L, von Boehmer H. 2002. Origin of regulatory $\mathrm{T}$ cells with known specificity for antigen. Nat Immunol 3: 756-763. 
Aricha R, Feferman T, Fuchs S, Souroujon MC. 2008. Ex vivo generated regulatory $\mathrm{T}$ cells modulate experimental autoimmune myasthenia gravis. J Immunol 180: 2132 2139.

Atarashi K, Tanoue T, Shima T, Imaoka A, Kuwahara T, Momose Y, Cheng G, Yamasaki S, Saito T, Ohba Y, et al. 2010. Induction of colonic regulatory $T$ cells by indigenous Clostridium species. Science 331: 337-341.

Bailey-Bucktrout SL, Bluestone JA. 2011. Regulatory T cells: Stability revisited. Trends Immunol 32: 301-306.

Barnes MJ, Krebs P, Harris N, Eidenschenk C, GonzalezQuintial R, Arnold CN, Crozat K, Sovath S, Moresco EM, Theofilopoulos AN, et al. 2009. Commitment to the regulatory $\mathrm{T}$ cell lineage requires CARMAl in the thymus but not in the periphery. PLoS Biol 7: e51.

Battaglia M, Stabilini A, Roncarolo MG. 2005. Rapamycin selectively expands $\mathrm{CD} 4{ }^{+} \mathrm{CD} 25^{+} \mathrm{FoxP}^{+}$regulatory $\mathrm{T}$ cells. Blood 105: 4743-4748.

Bautista JL, Lio CW, Lathrop SK, Forbush K, Liang Y, Luo J, Rudensky AY, Hsieh CS. 2009. Intraclonal competition limits the fate determination of regulatory $\mathrm{T}$ cells in the thymus. Nat Immunol 10: 610-617.

Belkaid Y, Tarbell K. 2009. Regulatory T cells in the control of host-microorganism interactions. Annu Rev Immunol 27: $551-589$.

Bensinger SJ, Walsh PT, Zhang J, Carroll M, Parsons R, Rathmell JC, Thompson CB, Burchill MA, Farrar MA, Turka LA. 2004. Distinct IL-2 receptor signaling pattern in $\mathrm{CD} 4{ }^{+} \mathrm{CD} 25^{+}$regulatory T cells. J Immunol 172: 5287 5296.

Benson MJ, Pino-Lagos K, Rosemblatt M, Noelle RJ. 2007. All-trans retinoic acid mediates enhanced $\mathrm{T}$ reg cell growth, differentiation, and gut homing in the face of high levels of co-stimulation. J Exp Med 204: 1765-1774.

Bettini ML, Pan F, Bettini M, Finkelstein D, Rehg JE, Floess S, Bell BD, Ziegler SF, Huehn J, Pardoll DM, et al. 2012. Loss of epigenetic modification driven by the Foxp3 transcription factor leads to regulatory $\mathrm{T}$ cell insufficiency. Immunity 36: 717-730.

Bienvenu B, Martin B, Auffray C, Cordier C, Becourt C, Lucas B. 2005. Peripheral CD $8^{+} \mathrm{CD} 25^{+}$T lymphocytes from MHC class II-deficient mice exhibit regulatory activity. J Immunol 175: 246-253.

Bisikirska B, Colgan J, Luban J, Bluestone JA, Herold KC 2005. TCR stimulation with modified anti-CD3 mAb expands $\mathrm{CD}^{+} \mathrm{T}$ cell population and induces $\mathrm{CD} 8^{+-}$ CD25 ${ }^{+}$Tregs. J Clin Invest 115: 2904-2913.

Bonasio R, Scimone ML, Schaerli P, Grabie N, Lichtman AH, von Andrian UH. 2006. Clonal deletion of thymocytes by circulating dendritic cells homing to the thymus. Nat Immunol 7: 1092-1100.

Brunkow ME, Jeffery EW, Hjerrild KA, Paeper B, Clark LB, Yasayko SA, Wilkinson JE, Galas D, Ziegler SF, Ramsdell F. 2001. Disruption of a new forkhead/winged-helix protein, scurfin, results in the fatal lymphoproliferative disorder of the scurfy mouse. Nat Genet 27: 68-73.

Brusko TM, Putnam AL, Bluestone JA. 2008. Human regulatory T cells: Role in autoimmune disease and therapeutic opportunities. Immunol Rev 223: 371-390.

Burchill MA, Yang J, Vang KB, Moon JJ, Chu HH, Lio CW, Vegoe AL, Hsieh CS, Jenkins MK, Farrar MA. 2008.
Linked $\mathrm{T}$ cell receptor and cytokine signaling govern the development of the regulatory $\mathrm{T}$ cell repertoire. Immunity 28: 112-121.

Chatila TA, Blaeser F, Ho N, Lederman MH, Voulgaropoulos C, Helms C, Bowcock AM. 2000. JM2, encoding a fork head-related protein, is mutated in X-linked autoimmunity-allergic disregulation syndrome. J Clin Invest 106: R75-R81.

Chaudhry A, Rudra D, Treuting P, Samstein RM, Liang Y, Kas A, Rudensky AY. 2009. CD4 ${ }^{+}$regulatory T cells control TH17 responses in a Stat3-dependent manner. Science 326: 986-991.

Chen W, Jin W, Hardegen N, Lei KJ, Li L, Marinos N, McGrady G, Wahl SM. 2003. Conversion of peripheral $\mathrm{CD} 4{ }^{+} \mathrm{CD} 25^{-}$naive $\mathrm{T}$ cells to $\mathrm{CD} 4{ }^{+} \mathrm{CD} 25^{+}$regulatory T cells by TGF- $\beta$ induction of transcription factor Foxp3. $J$ Exp Med 198: 1875-1886.

Chen Z, Herman AE, Matos M, Mathis D, Benoist C. 2005. Where $\mathrm{CD} 4{ }^{+} \mathrm{CD} 25^{+}$Treg cells impinge on autoimmune diabetes. J Exp Med 202: 1387-1397.

Chen Y, Haines CJ, Gutcher I, Hochweller K, Blumenschein WM, McClanahan T, Hammerling G, Li MO, Cua DJ, McGeachy MJ. 2011. Foxp $3^{+}$regulatory T cells promote T helper 17 cell development in vivo through regulation of interleukin-2. Immunity 34: 409-421.

Coombes JL, Siddiqui KR, Arancibia-Carcamo CV, Hall J, Sun CM, Belkaid Y, Powrie F. 2007. A functionally specialized population of mucosal $\mathrm{CD}_{103}{ }^{+}$DCs induces Foxp $3^{+}$regulatory $\mathrm{T}$ cells via a TGF- $\beta$ and retinoic acid-dependent mechanism. J Exp Med 204: 1757-1764.

Cozzo PC, Simons DM, Oh S, Aitken M, Perng OA, Mergenthaler C, Kropf E, Erikson J, Caton AJ. 2011. CD4 ${ }^{+}$ $\mathrm{CD} 25^{+} \mathrm{Foxp}^{+}{ }^{+}$regulatory $\mathrm{T}$ cell formation requires more specific recognition of a self-peptide than thymocyte deletion. Proc Natl Acad Sci 108: 14890-14895.

Curotto de Lafaille MA, Kutchukhidze N, Shen S, Ding Y, Yee H, Lafaille JJ. 2008. Adaptive Foxp $3^{+}$regulatory T cell-dependent and -independent control of allergic inflammation. Immunity 29: 114-126.

D’Alise AM, Ergun A, Hill JA, Mathis DM, Benoist C. 2011. A cluster of coregulated genes determines TGF- $\beta$-induced regulatory T-cell (Treg) dysfunction in NOD mice. Proc Natl Acad Sci 108: 8737-8742.

Dang EV, Barbi J, Yang HY, Jinasena D, Yu H, Zheng Y, Bordman Z, Fu J, Kim Y, Yen HR, et al. 2011. Control of $\mathrm{T}(\mathrm{H}) 17 / \mathrm{T}(\mathrm{reg})$ balance by hypoxia-inducible factor 1 . Cell 146: 772-784.

Daniel C, Wennhold K, Kim HJ, von Boehmer H. 2010. Enhancement of antigen-specific Treg vaccination in vivo. Proc Natl Acad Sci 107: 16246-16251.

Darce J, Rudra D, Li L, Nishio J, Cipolletta D, Rudensky AY, Mathis D, Benoist C. 2012. An N-terminal mutation of the Foxp3 transcription factor alleviates arthritis but exacerbates diabetes. Immunity 36: 731-741.

Davidson TS, Shevach EM. 2011. Polyclonal Treg cells modulate $\mathrm{T}$ effector cell trafficking. Eur J Immunol 41: 2862-2870.

Davidson TS, Dipaolo RJ, Andersson J, Shevach EM. 2007. Cutting edge: IL-2 is essential for TGF- $\beta$-mediated induction of Foxp $3^{+}$T regulatory cells. J Immunol 178: 4022-4026. 
Delgoffe GM, Pollizzi KN, Waickman AT, Heikamp E, Meyers DJ, Horton MR, Xiao B, Worley PF, Powell JD. 2011. The kinase mTOR regulates the differentiation of helper $\mathrm{T}$ cells through the selective activation of signaling by mTORC1 and mTORC2. Nat Immunol 12: 295-303.

Dipaolo RJ, Shevach EM. 2009. CD4 ${ }^{+}$T-cell development in a mouse expressing a transgenic TCR derived from a Treg. Eur J Immunol 39: 234-240.

Duarte JH, Zelenay S, Bergman ML, Martins AC, Demengeot J. 2009. Natural Treg cells spontaneously differentiate into pathogenic helper cells in lymphopenic conditions. Eur J Immunol 39: 948-955.

Elias KM, Laurence A, Davidson TS, Stephens G, Kanno Y, Shevach EM, O'Shea JJ. 2008. Retinoic acid inhibits Th17 polarization and enhances FoxP3 expression through a Stat-3/Stat-5 independent signaling pathway. Blood 111: 1013-1020.

Facciabene A, Peng X, Hagemann IS, Balint K, Barchetti A, Wang LP, Gimotty PA, Gilks CB, Lal P, Zhang L, et al. 2011. Tumour hypoxia promotes tolerance and angiogenesis via CCL28 and T(reg) cells. Nature 475: 226-230.

Fantini MC, Becker C, Monteleone G, Pallone F, Galle PR, Neurath MF. 2004. Cutting edge: TGF- $\beta$ induces a regulatory phenotype in $\mathrm{CD}^{+}{ }^{+}$. J Immunol 172: 5149-5153.

Fassett MS, Jiang W, D’Alise AM, Mathis D, Benoist C. 2012. Nuclear receptor Nr4a1 modulates both regulatory T-cell (Treg) differentiation and clonal deletion. Proc Natl Acad Sci 109: 3891-3896.

Feuerer M, Herrero L, Cipolletta D, Naaz A, Wong J, Nayer A, Lee J, Goldfine AB, Benoist C, Shoelson S, et al. 2009a. Lean, but not obese, fat is enriched for a unique population of regulatory $\mathrm{T}$ cells that affect metabolic parameters. Nat Med 15: 930-939.

Feuerer M, Hill JA, Mathis D, Benoist C. 2009b. Foxp3 ${ }^{+}$ regulatory T cells: Differentiation, specification, subphenotypes. Nat Immunol 10: 689-695.

Feuerer M, Shen Y, Littman DR, Benoist C, Mathis D. 2009c. How punctual ablation of regulatory $\mathrm{T}$ cells unleashes an autoimmune lesion within the pancreatic islets. Immunity 31: 654-664.

Feuerer M, Hill JA, Kretschmer K, von Boehmer H, Mathis D, Benoist C. 2010. Genomic definition of multiple ex vivo regulatory T cell subphenotypes. Proc Natl Acad Sci 107: 5919-5924.

Finney CA, Taylor MD, Wilson MS, Maizels RM. 2007. Expansion and activation of $\mathrm{CD} 4{ }^{+} \mathrm{CD} 25^{+}$regulatory $\mathrm{T}$ cells in Heligmosomoides polygyrus infection. Eur J Immunol 37: 1874-1886.

Fisson S, Darrasse-Jeze G, Litvinova E, Septier F, Klatzmann D, Liblau R, Salomon BL. 2003. Continuous activation of autoreactive $\mathrm{CD} 4^{+} \mathrm{CD} 25^{+}$regulatory T cells in the steady state. J Exp Med 198: 737-746.

Fletcher JM, Lonergan R, Costelloe L, Kinsella K, Moran B, O'Farrelly C, Tubridy N, Mills KH. 2009. CD $39^{+}$Foxp $^{+}$ regulatory $\mathrm{T}$ cells suppress pathogenic Th17 cells and are impaired in multiple sclerosis. J Immunol 183: $7602-$ 7610.

Floess S, Freyer J, Siewert C, Baron U, Olek, Polansky J, Schlawe K, Chang HD, Bopp T, Schmitt E, et al. 2007. Epigenetic control of the foxp3 locus in regulatory $\mathrm{T}$ cells. PLoS Biol 5: e38.
Fontenot JD, Gavin MA, Rudensky AY. 2003. Foxp3 programs the development and function of $\mathrm{CD} 4{ }^{+} \mathrm{CD} 25^{+}$ regulatory T cells. Nat Immunol 4: 330-336.

Fontenot JD, Rasmussen JP, Gavin MA, Rudensky AY. 2005a. A function for interleukin 2 in Foxp3-expressing regulatory T cells. Nat Immunol 6: 1142-1151.

Fontenot JD, Rasmussen JP, Williams LM, Dooley JL, Farr AG, Rudensky AY. 2005b. Regulatory T cell lineage specification by the forkhead transcription factor foxp3. Immunity 22: 329-341.

Furtado GC, Curotto de Lafaille MA, Kutchukhidze N, Lafaille JJ. 2002. Interleukin 2 signaling is required for $\mathrm{CD}^{+}{ }^{+}$regulatory T cell function. J Exp Med 196: 851857.

Germain RN. 2008. Special regulatory T-cell review: A rose by any other name: From suppressor T cells to Tregs, approbation to unbridled enthusiasm. Immunology 123: $20-27$.

Gottschalk RA, Corse E, Allison JP. 2012. Expression of Helios in peripherally induced Foxp $3^{+}$regulatory T cells. J Immunol 188: 976-980.

Grainger JR, Smith KA, Hewitson JP, McSorley HJ, Harcus Y, Filbey KJ, Finney CA, Greenwood EJ, Knox DP, Wilson MS, et al. 2010. Helminth secretions induce de novo T cell Foxp3 expression and regulatory function through the TGF- $\beta$ pathway. J Exp Med 207: 2331-2341.

Hadis U, Wahl B, Schulz O, Hardtke-Wolenski M, Schippers A, Wagner N, Muller W, Sparwasser T, Forster R, Pabst O. 2011. Intestinal tolerance requires gut homing and expansion of $\mathrm{FoxP}^{+}$regulatory $\mathrm{T}$ cells in the lamina propria. Immunity 34: 237-246.

Hall JA, Cannons JL, Grainger JR, Dos Santos LM, Hand TW, Naik S, Wohlfert EA, Chou DB, Oldenhove G, Robinson $\mathrm{M}$, et al. 2011. Essential role for retinoic acid in the promotion of $\mathrm{CD}^{+} \mathrm{T}$ cell effector responses via retinoic acid receptor $\alpha$. Immunity 34: 435-447.

Haribhai D, Lin W, Edwards B, Ziegelbauer J, Salzman NH, Carlson MR, Li SH, Simpson PM, Chatila TA, Williams CB. 2009. A central role for induced regulatory T cells in tolerance induction in experimental colitis. J Immunol 182: $3461-3468$.

Haribhai D, Williams JB, Jia S, Nickerson D, Schmitt EG, Edwards B, Ziegelbauer J, Yassai M, Li SH, Relland LM, et al. 2011. A requisite role for induced regulatory T cells in tolerance based on expanding antigen receptor diversity. Immunity 35: 109-122.

Haxhinasto S, Mathis D, Benoist C. 2008. The AKT-mTOR axis regulates de novo differentiation of $\mathrm{CD}^{+}{ }^{+} \mathrm{Foxp} 3^{+}$ cells. J Exp Med 205: 565-574.

Hill JA, Feuerer M, Tash K, Haxhinasto S, Perez J, Melamed R, Mathis D, Benoist C. 2007. Foxp3 transcription-factordependent and -independent regulation of the regulatory $\mathrm{T}$ cell transcriptional signature. Immunity 27: 786-800.

Hill JA, Hall JA, Sun CM, Cai Q, Ghyselinck N, Chambon P, Belkaid Y, Mathis D, Benoist C. 2008. Retinoic acid enhances Foxp3 induction indirectly by relieving inhibition from $\mathrm{CD} 4{ }^{+} \mathrm{CD} 44$ hi cells. Immunity 29: 758-770.

Hori S, Nomura T, Sakaguchi S. 2003. Control of regulatory $\mathrm{T}$ cell development by the transcription factor Foxp3. Science 299: 1057-1061. 
Hsieh CS, Zheng Y, Liang Y, Fontenot JD, Rudensky AY 2006. An intersection between the self-reactive regulatory and nonregulatory $\mathrm{T}$ cell receptor repertoires. Nat Immunol 7: 401-410.

Huehn J, Polansky JK, Hamann A. 2009. Epigenetic control of FOXP3 expression: The key to a stable regulatory T-cell lineage? Nat Rev Immunol 9: 83-89.

Huter EN, Punkosdy GA, Glass DD, Cheng LI, Ward JM, Shevach EM. 2008. TGF- $\beta$-induced Foxp $3^{+}$regulatory T cells rescue scurfy mice. Eur J Immunol 38: 1814-1821.

Jordan MS, Boesteanu A, Reed AJ, Petrone AL, Holenbeck AE, Lerman MA, Naji A, Caton AJ. 2001. Thymic selection of $\mathrm{CD} 4{ }^{+} \mathrm{CD} 25^{+}$regulatory $\mathrm{T}$ cells induced by an agonist self-peptide. Nat Immunol 2: 283-284.

Kawahata K, Misaki Y, Yamauchi M, Tsunekawa S, Setoguchi K, Miyazaki J, Yamamoto J. 2002. Generation of CD4 ${ }^{+}$ $\mathrm{CD} 25^{+}$regulatory $\mathrm{T}$ cells from autoreactive $\mathrm{T}$ cells simultaneously with their negative selection in the thymus and from nonautoreactive T cells by endogenous TCR expression. J Immunol 168: 4399-4405.

Kerdiles YM, Stone EL, Beisner DR, McGargill MA, Ch'en IL, Stockmann C, Katayama CD, Hedrick SM. 2010. Foxo transcription factors control regulatory $\mathrm{T}$ cell development and function. Immunity 33: 890-904.

Khattri R, Cox T, Yasayko SA, Ramsdell F. 2003. An essential role for Scurfin in $\mathrm{CD} 4{ }^{+} \mathrm{CD} 25^{+}$T regulatory cells. Nat Immunol 4: 337-342.

Kim JM, Rasmussen JP, Rudensky AY. 2007. Regulatory T cells prevent catastrophic autoimmunity throughout the lifespan of mice. Nat Immunol 8: 191-197.

Koch MA, Tucker-Heard G, Perdue NR, Killebrew JR, Urdahl KB, Campbell DJ. 2009. The transcription factor Tbet controls regulatory $\mathrm{T}$ cell homeostasis and function during type 1 inflammation. Nat Immunol 10: 595-602.

Komatsu N, Mariotti-Ferrandiz ME, Wang Y, Malissen B, Waldmann H, Hori S. 2009. Heterogeneity of natural Foxp $3^{+} \mathrm{T}$ cells: A committed regulatory T-cell lineage and an uncommitted minor population retaining plasticity. Proc Natl Acad Sci 106: 1903-1908.

Korn T, Reddy J, Gao W, Bettelli E, Awasthi A, Petersen TR, Backstrom BT, Sobel RA, Wucherpfennig KW, Strom TB, et al. 2007. Myelin-specific regulatory T cells accumulate in the CNS but fail to control autoimmune inflammation. Nat Med 13: 423-431.

Krajina T, Leithauser F, Reimann J. 2004. MHC class IIindependent $\mathrm{CD} 25^{+} \mathrm{CD} 4^{+} \mathrm{CD} 8 \alpha \beta^{+} \alpha \beta$ T cells attenuate $\mathrm{CD}^{+} \mathrm{T}$ cell-induced transfer colitis. Eur J Immunol 34: 705-714.

Kretschmer K, Apostolou I, Hawiger D, Khazaie K, Nussenzweig MC, von Boehmer H. 2005. Inducing and expanding regulatory $\mathrm{T}$ cell populations by foreign antigen. Nat Immunol 6: 1219-1227.

Lathrop SK, Santacruz NA, Pham D, Luo J, Hsieh CS. 2008 Antigen-specific peripheral shaping of the natural regulatory T cell population. J Exp Med 205: 3105-3117.

Lathrop SK, Bloom SM, Rao SM, Nutsch K, Lio CW, Santacruz N, Peterson DA, Stappenbeck TS, Hsieh CS. 2011. Peripheral education of the immune system by colonic commensal microbiota. Nature 478: 250-254.
Leung MW, Shen S, Lafaille JJ. 2009. TCR-dependent differentiation of thymic Foxp $3^{+}$cells is limited to small clonal sizes. J Exp Med 206: 2121-2130.

Linterman MA, Pierson W, Lee SK, Kallies A, Kawamoto S, Rayner TF, Srivastava M, Divekar DP, Beaton L, Hogan JJ, et al. 2011. Foxp $3^{+}$follicular regulatory T cells control the germinal center response. Nat Med 17: 975-982.

Lio CW, Hsieh CS. 2008. A two-step process for thymic regulatory T cell development. Immunity 28: 100-111.

Lio CW, Dodson LF, Deppong CM, Hsieh CS, Green JM. 2010. CD28 facilitates the generation of Foxp $3^{-}$cytokine responsive regulatory T cell precursors. J Immunol 184: 6007-6013.

Liston A, Lesage S, Wilson J, Peltonen L, Goodnow CC. 2003. Aire regulates negative selection of organ-specific T cells. Nat Immunol 4: 350-354.

Littman DR, Rudensky AY. 2010. Th17 and regulatory T cells in mediating and restraining inflammation. Cell 140: 845-858.

Liu Y, Zhang P, Li J, Kulkarni AB, Perruche S, Chen W. 2008. A critical function for TGF- $\beta$ signaling in the development of natural $\mathrm{CD} 4^{+} \mathrm{CD} 25^{+} \mathrm{Foxp}^{+}$regulatory T cells. Nat Immunol 9: 632-640.

Liu X, Nguyen P, Liu W, Cheng C, Steeves M, Obenauer JC, Ma J, Geiger TL. 2009. T cell receptor CDR3 sequence but not recognition characteristics distinguish autoreactive effector and Foxp $3^{+}$regulatory $\mathrm{T}$ cells. Immunity 31: 909-920.

Long M, Park SG, Strickland I, Hayden MS, Ghosh S. 2009. Nuclear factor- $\mathrm{\kappa B}$ modulates regulatory $\mathrm{T}$ cell development by directly regulating expression of Foxp3 transcription factor. Immunity 31: 921-931.

Lund JM, Hsing L, Pham TT, Rudensky AY. 2008. Coordination of early protective immunity to viral infection by regulatory T cells. Science 320: 1220-1224.

Malek TR, Yu A, Vincek V, Scibelli P, Kong L. 2002. CD4 regulatory $\mathrm{T}$ cells prevent lethal autoimmunity in IL2R $\beta$-deficient mice. Implications for the nonredundant function of IL-2. Immunity 17: 167-178.

McSorley HJ, Harcus YM, Murray J, Taylor MD, Maizels RM. 2008. Expansion of Foxp $3^{+}$regulatory T cells in mice infected with the filarial parasite Brugia malayi. J Immunol 181: 6456-6466.

Medoff BD, Sandall BP, Landry A, Nagahama K, Mizoguchi A, Luster AD, Xavier RJ. 2009. Differential requirement for CARMA1 in agonist-selected T-cell development. Eur J Immunol 39: 78-84.

Menning A, Loddenkemper C, Westendorf AM, Szilagyi B, Buer J, Siewert C, Hamann A, Huehn J. 2010. Retinoic acid-induced gut tropism improves the protective capacity of Treg in acute but not in chronic gut inflammation. Eur J Immunol 40: 2539-2548.

Miyao T, Floess S, Setoguchi R, Luche H, Fehling HJ, Waldmann H, Huehn J, Hori S. 2012. Plasticity of foxp $3^{+}$T cells reflects promiscuous foxp3 expression in conventional $\mathrm{T}$ cells but not reprogramming of regulatory $\mathrm{T}$ cells. Immunity 36: 262-275.

Moran AE, Holzapfel KL, Xing Y, Cunningham RL, Maltzman JS, Punt J, Hogquist KA. 2011. T cell receptor signal strength in Treg and iNKT cell development 
demonstrated by a novel fluorescent reporter mouse. $J$ Exp Med 208: 1279-1289.

Morrissey PJ, Charrier K, Braddy S, Liggitt D, Watson JD. 1993. $\mathrm{CD}^{+} \mathrm{T}$ cells that express high levels of CD45RB induce wasting disease when transferred into congenic severe combined immunodeficient mice. Disease development is prevented by cotransfer of purified $\mathrm{CD} 4^{+} \mathrm{T}$ cells. J Exp Med 178: 237-244.

Mucida D, Park Y, Kim G, Turovskaya O, Scott I, Kronenberg M, Cheroutre H. 2007. Reciprocal Th-17 and regulatory $\mathrm{T}$ cell differentiation mediated by retinoic acid. Science 317: $256-260$.

Nishimura E, Sakihama T, Setoguchi R, Tanaka K, Sakaguchi S. 2004. Induction of antigen-specific immunologic tolerance by in vivo and in vitro antigen-specific expansion of naturally arising Foxp $3^{+} \mathrm{CD} 25^{+} \mathrm{CD} 4^{+}$regulatory $\mathrm{T}$ cells. Int Immunol 16: 1189-1201.

Nishio J, Feuerer M, Wong J, Mathis D, Benoist C. 2010 Anti-CD3 therapy permits regulatory $\mathrm{T}$ cells to surmount $\mathrm{T}$ cell receptor-specified peripheral niche constraints. J Exp Med 207: 1879-1889.

Nolting J, Daniel C, Reuter S, Stuelten C, Li P, Sucov H, Kim BF, Letterio JJ, Kretschmer K, Kim HJ, et al. 2009. Retinoic acid can enhance conversion of naive into regulatory $\mathrm{T}$ cells independently of secreted cytokines. J Exp Med 206: $2131-2139$.

Oldenhove G, Bouladoux N, Wohlfert EA, Hall JA, Chou D, Dos SL, O’Brien S, Blank R, Lamb E, Natarajan S, et al. 2009. Decrease of Foxp ${ }^{+}$Treg cell number and acquisition of effector cell phenotype during lethal infection. Immunity 31: 772-786.

Ouyang W, Beckett O, Ma Q, Paik JH, DePinho RA, Li MO. 2010. Foxo proteins cooperatively control the differentiation of Foxp $3^{+}$regulatory T cells. Nat Immunol 11:618627.

Pacholczyk R, Ignatowicz H, Kraj P, Ignatowicz L. 2006. Origin and T cell receptor diversity of $\mathrm{Foxp}^{+} \mathrm{CD}^{+}$ $\mathrm{CD}^{2} 5^{+} \mathrm{T}$ cells. Immunity 25: 249-259.

Pacholczyk R, Kern J, Singh N, Iwashima M, Kraj P, Ignatowicz L. 2007. Nonself-antigens are the cognate specificities of Foxp $3^{+}$regulatory T cells. Immunity 27: 493-504.

Peng Y, Laouar Y, Li MO, Green EA, Flavell RA. 2004. TGF- $\beta$ regulates in vivo expansion of Foxp3-expressing $\mathrm{CD} 4^{+}$ $\mathrm{CD}^{2} 5^{+}$regulatory $\mathrm{T}$ cells responsible for protection against diabetes. Proc Natl Acad Sci 101: 4572-4577.

Powrie F, Mason D. 1990. OX-22high CD4 ${ }^{+}$T cells induce wasting disease with multiple organ pathology: Prevention by the OX-22low subset. J Exp Med 172: 1701-1708.

Qu Y, Zhang B, Zhao L, Liu G, Ma H, Rao E, Zeng C, Zhao Y. 2007. The effect of immunosuppressive drug rapamycin on regulatory $\mathrm{CD} 4^{+} \mathrm{CD} 25^{+} \mathrm{Foxp}^{+} \mathrm{T}$ cells in mice. Transpl Immunol 17: 153-161.

Ruan Q, Kameswaran V, Tone Y, Li L, Liou HC, Greene MI, Tone M, Chen YH. 2009. Development of Foxp $3^{+}$regulatory $\mathrm{T}$ cells is driven by the c-Rel enhanceosome. Immunity 31: 932-940.

Rubtsov YP, Niec RE, Josefowicz S, Li L, Darce J, Mathis D, Benoist C, Rudensky AY. 2010. Stability of the regulatory T cell lineage in vivo. Science 329: 1667-1671.

Rudensky AY. 2011. Regulatory T cells and Foxp3. Immunol Rev 241: 260-268.
Sakaguchi S, Takahashi T, Nishizuka Y. 1982. Study on cellular events in post-thymectomy autoimmune oophoritis in mice. II. Requirement of Lyt-1 cells in normal female mice for the prevention of oophoritis. J Exp Med 156: 1577-1586.

Sakaguchi S, Sakaguchi N, Asano M, Itoh M, Toda M. 1995. Immunologic self-tolerance maintained by activated $\mathrm{T}$ cells expressing IL-2 receptor $\alpha$-chains (CD25). Breakdown of a single mechanism of self-tolerance causes various autoimmune diseases. J Immunol 155: 1151-1164.

Sakaguchi S, Yamaguchi T, Nomura T, Ono M. 2008. Regulatory T cells and immune tolerance. Cell 133: 775-787.

Salomon B, Lenschow DJ, Rhee L, Ashourian N, Singh B, Sharpe A, Bluestone JA. 2000. B7/CD28 costimulation is essential for the homeostasis of the $\mathrm{CD} 4^{+} \mathrm{CD} 25^{+}$immunoregulatory $\mathrm{T}$ cells that control autoimmune diabetes. Immunity 12: 431-440.

Samstein RM, Josefowicz SZ, Arvey A, Treuting PM, Rudensky AY. 2012. Extrathymic generation of regulatory T cells in placental mammals mitigates maternal-fetal conflict. Cell 150: 29-38.

Sarween N, Chodos A, Raykundalia C, Khan M, Abbas AK, Walker LS. 2004. CD $4^{+} \mathrm{CD} 25^{+}$cells controlling a pathogenic CD4 response inhibit cytokine differentiation, CXCR-3 expression, and tissue invasion. I Immunol 173: $2942-2951$.

Sato S, Sanjo H, Tsujimura T, Ninomiya-Tsuji J, Yamamoto M, Kawai T, Takeuchi O, Akira S. 2006. TAK1 is indispensable for development of $\mathrm{T}$ cells and prevention of colitis by the generation of regulatory $\mathrm{T}$ cells. Int Immunol 18: 1405-1411.

Sauer S, Bruno L, Hertweck A, Finlay D, Leleu M, Spivakov M, Knight ZA, Cobb BS, Cantrell D, O'Connor E, et al. 2008. T cell receptor signaling controls Foxp3 expression via PI3K, Akt, and mTOR. Proc Natl Acad Sci 105: 7797-7802.

Schmidt-Supprian M, Courtois G, Tian J, Coyle AJ, Israel A, Rajewsky K, Pasparakis M. 2003. Mature T cells depend on signaling through the IKK complex. Immunity 19: 377-389.

Schmidt-Supprian M, Tian J, Grant EP, Pasparakis M, Maehr R, Ovaa H, Ploegh HL, Coyle AJ, Rajewsky K. 2004. Differential dependence of $\mathrm{CD} 4^{+} \mathrm{CD} 25^{+}$regulatory and natural killer-like $\mathrm{T}$ cells on signals leading to NFкB activation. Proc Natl Acad Sci 101: 4566-4571.

Serre K, Benezech C, Desanti G, Bobat S, Toellner KM, Bird R, Chan S, Kastner P, Cunningham AF, Maclennan IC, et al. 2011. Helios is associated with CD4 T cells differentiating to Thelper 2 and follicular helper T cells in vivo independently of Foxp3 expression. PLoS ONE 6: e20731.

Setoguchi R, Hori S, Takahashi T, Sakaguchi S. 2005. Homeostatic maintenance of natural Foxp $3^{+} \mathrm{CD} 25^{+} \mathrm{CD} 4^{+}$ regulatory $\mathrm{T}$ cells by interleukin (IL)- 2 and induction of autoimmune disease by IL-2 neutralization. J Exp Med 201: 723-735.

Shevach EM. 2009. Mechanisms of foxp $3^{+}$Tregulatory cellmediated suppression. Immunity 30: 636-645.

Shi LZ, Wang R, Huang G, Vogel P, Neale G, Green DR, Chi H. 2011. HIFl $\alpha$-dependent glycolytic pathway orchestrates a metabolic checkpoint for the differentiation of TH17 and Treg cells. J Exp Med 208: 1367-1376. 
Siegmund K, Feuerer M, Siewert C, Ghani S, Haubold U, Dankof A, Krenn V, Schon MP, Scheffold A, Lowe JB, et al. 2005. Migration matters: Regulatory T-cell compartmentalization determines suppressive activity in vivo. Blood 106: 3097-3104

Smith H, Sakamoto Y, Kasai K, Tung KS. 1991. Effector and regulatory cells in autoimmune oophoritis elicited by neonatal thymectomy. J Immunol 147: 2928-2933.

Stephens GL, Andersson J, Shevach EM. 2007. Distinct subsets of FoxP $3^{+}$regulatory T cells participate in the contro of immune responses. J Immunol 178: 6901-6911.

Strauss L, Whiteside TL, Knights A, Bergmann C, Knuth A, Zippelius A. 2007. Selective survival of naturally occurring human $\mathrm{CD}^{+} \mathrm{CD}^{+} 5^{+} \mathrm{Foxp}^{+}$regulatory T cells cultured with rapamycin. J Immunol 178: 320-329.

Suffia IJ, Reckling SK, Piccirillo CA, Goldszmid RS, Belkaid Y. 2006. Infected site-restricted Foxp $3^{+}$natural regulatory $\mathrm{T}$ cells are specific for microbial antigens. J Exp Med 203: $777-788$.

Sun CM, Hall JA, Blank RB, Bouladoux N, Oukka M, Mora JR, Belkaid Y. 2007. Small intestine lamina propria dendritic cells promote de novo generation of Foxp3 T reg cells via retinoic acid. J Exp Med 204: 1775-1785.

Suri-Payer E, Amar AZ, Thornton AM, Shevach EM. 1998. $\mathrm{CD} 4{ }^{+} \mathrm{CD} 25^{+} \mathrm{T}$ cells inhibit both the induction and effector function of autoreactive $\mathrm{T}$ cells and represent a unique lineage of immunoregulatory cells. J Immuno 160: $1212-1218$

Tai X, Cowan M, Feigenbaum L, Singer A. 2005. CD28 costimulation of developing thymocytes induces Foxp3 expression and regulatory $\mathrm{T}$ cell differentiation independently of interleukin 2. Nat Immunol 6: 152-162.

Takahashi T, Kuniyasu Y, Toda M, Sakaguchi N, Itoh M, Iwata M, Shimizu J, Sakaguchi S. 1998. Immunologic self-tolerance maintained by $\mathrm{CD} 25^{+} \mathrm{CD} 4^{+}$naturally anergic and suppressive T cells: Induction of autoimmune disease by breaking their anergic/suppressive state. Int Immunol 10: 1969-1980.

Takahashi T, Tagami T, Yamazaki S, Uede T, Shimizu J, Sakaguchi N, Mak TW, Sakaguchi S. 2000. Immunologic self-tolerance maintained by $\mathrm{CD} 25^{+} \mathrm{CD} 4^{+}$regulatory T cells constitutively expressing cytotoxic $\mathrm{T}$ lymphocyteassociated antigen 4. J Exp Med 192: 303-310.

Tang Q, Henriksen KJ, Bi M, Finger EB, Szot G, Ye J, Masteller EL, McDevitt H, Bonyhadi M, Bluestone JA. 2004 In vitro-expanded antigen-specific regulatory $\mathrm{T}$ cells suppress autoimmune diabetes. J Exp Med 199: 1455-1465.

Tang Q, Adams JY, Tooley AJ, Bi M, Fife BT, Serra P, Santamaria P, Locksley RM, Krummel MF, Bluestone JA. 2006. Visualizing regulatory $\mathrm{T}$ cell control of autoimmune responses in nonobese diabetic mice. Nat Immunol 7: $83-92$.

Tarbell KV, Yamazaki S, Olson K, Toy P, Steinman RM. 2004. $\mathrm{CD} 25^{+} \mathrm{CD} 4{ }^{+} \mathrm{T}$ cells, expanded with dendritic cells presenting a single autoantigenic peptide, suppress autoimmune diabetes. J Exp Med 199: 1467-1477.

Thornton AM, Shevach EM. 1998. CD4 ${ }^{+} \mathrm{CD} 25^{+}$immunoregulatory $\mathrm{T}$ cells suppress polyclonal $\mathrm{T}$ cell activation in vitro by inhibiting interleukin 2 production. J Exp Med 188: 287-296.

Thornton AM, Donovan EE, Piccirillo CA, Shevach EM. 2004. Cutting edge: IL-2 is critically required for the in vitro activation of $\mathrm{CD} 44^{+} \mathrm{CD} 25^{+} \mathrm{T}$ cell suppressor function. J Immunol 172: 6519-6523.

Thornton AM, Korty PE, Tran DQ, Wohlfert EA, Murray PE, Belkaid Y, Shevach EM. 2010. Expression of Helios, an Ikaros transcription factor family member, differentiates thymic-derived from peripherally induced Foxp $3^{+} \mathrm{T}$ regulatory cells. J Immunol 184: 3433-3441.

Tsuji M, Komatsu N, Kawamoto S, Suzuki K, Kanagawa O, Honjo T, Hori S, Fagarasan S. 2009. Preferential generation of follicular B helper T cells from Foxp $3^{+} \mathrm{T}$ cells in gut Peyer's patches. Science 323: 1488-1492.

Van Santen HM, Benoist C, Mathis D. 2004. Number of Treg cells that differentiate does not increase upon encounter of agonist ligand on thymic epithelial cells. J Exp Med 200: $1221-1230$.

Verhagen J, Wraith DC. 2010. Comment on "Expression of Helios, an Ikaros transcription factor family member differentiates thymic-derived from peripherally induced Foxp $3^{+}$T regulatory cells." J Immunol 185: 7129 .

Vignali DA, Collison LW, Workman CJ. 2008. How regulatory T cells work. Nat Rev Immunol 8: 523-532.

Walker LS, Chodos A, Eggena M, Dooms H, Abbas AK. 2003. Antigen-dependent proliferation of $\mathrm{CD} 4^{+} \mathrm{CD} 25^{+}$ regulatory T cells in vivo. J Exp Med 198: 249-258.

Wan YY, Flavell RA. 2005. Identifying Foxp3-expressing suppressor T cells with a bicistronic reporter. Proc Natl Acad Sci 102: 5126-5131.

Wan YY, Chi H, Xie M, Schneider MD, Flavell RA. 2006. The kinase TAK1 integrates antigen and cytokine receptor signaling for $\mathrm{T}$ cell development, survival and function. Nat Immunol 7: 851-858.

Wei S, Kryczek I, Zou W. 2006. Regulatory T-cell compartmentalization and trafficking. Blood 108: 426-431.

Wildin RS, Ramsdell F, Peake J, Faravelli F, Casanova JL, Buist N, Levy-Lahad E, Mazzella M, Goulet O, Perroni L, et al. 2001. X-linked neonatal diabetes mellitus, enteropathy and endocrinopathy syndrome is the human equivalent of mouse scurfy. Nat Genet 27: 18-20.

Wong J, Mathis D, Benoist C. 2007a. TCR-based lineage tracing: No evidence for conversion of conventional into regulatory $\mathrm{T}$ cells in response to a natural self-antigen in pancreatic islets. J Exp Med 204: 2039-2045.

Wong J, Obst R, Correia-Neves M, Losyev G, Mathis D, Benoist C. 2007b. Adaptation of TCR repertoires to self-peptides in regulatory and nonregulatory $\mathrm{CD}^{+} \mathrm{T}$ cells. J Immunol 178: 7032-7041.

* Xing Y, Hogquist KA. 2012. T-cell tolerance: Central and peripheral. Cold Spring Harb Perspect Biol doi: 10.1101/ cshperspect.a006957.

Yu A, Zhu L, Altman NH, Malek TR. 2009. A low interleukin-2 receptor signaling threshold supports the development and homeostasis of Tregulatory cells. Immunity 30: 204-217.

Zheng XX, Sanchez-Fueyo A, Sho M, Domenig C, Sayegh MH, Strom TB. 2003. Favorably tipping the balance between cytopathic and regulatory $\mathrm{T}$ cells to create transplantation tolerance. Immunity 19: 503-514.

Zheng Y, Chaudhry A, Kas A, Deroos P, Kim JM, Chu TT, Corcoran L, Treuting P, Klein U, Rudensky AY. 2009. Regulatory T-cell suppressor program co-opts transcription factor IRF4 to control T(H)2 responses. Nature 458: $351-356$. 
C. Benoist and D. Mathis

Zheng Y, Josefowicz S, Chaudhry A, Peng XP, Forbush K, Rudensky AY. 2010. Role of conserved non-coding DNA elements in the Foxp3 gene in regulatory T-cell fate. $\mathrm{Na}$ ture 463: 808-812.

Zhou X, Bailey-Bucktrout SL, Jeker LT, Penaranda C, Martinez-Llordella M, Ashby M, Nakayama M, Rosen- thal W, Bluestone JA. 2009. Instability of the transcription factor Foxp3 leads to the generation of pathogenic memory T cells in vivo. Nat Immunol 10: 10001007.

Ziegler SF. 2006. FOXP3: Of mice and men. Annu Rev Immunol 24: 209-226. 


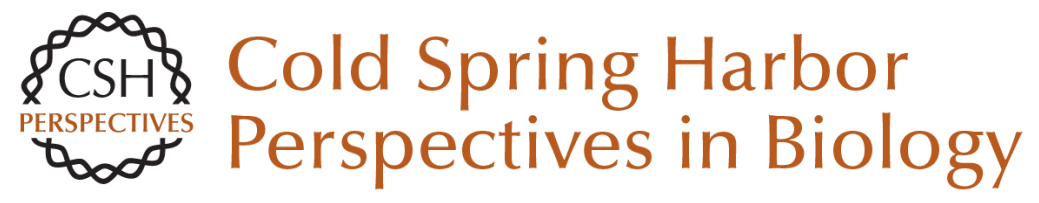

\section{Treg Cells, Life History, and Diversity}

Christophe Benoist and Diane Mathis

Cold Spring Harb Perspect Biol 2012; doi: 10.1101/cshperspect.a007021

Subject Collection Immune Tolerance

Regulatory T Cells and Immune Tolerance in the Intestine

Oliver J. Harrison and Fiona M. Powrie

Dendritic Cells: Arbiters of Immunity and

Immunological Tolerance

Kanako L. Lewis and Boris Reizis

Current and Future Immunomodulation Strategies

to Restore Tolerance in Autoimmune Diseases Jeffrey A. Bluestone and Hélène Bour-Jordan

T-Cell Tolerance: Central and Peripheral Yan Xing and Kristin A. Hogquist

Central B-Cell Tolerance: Where Selection Begins Roberta Pelanda and Raul M. Torres

The Immunogenetic Architecture of Autoimmune Disease

An Goris and Adrian Liston
Regulatory T Cells and Immune Tolerance in the Intestine

Oliver J. Harrison and Fiona M. Powrie

Microbiota and Autoimmunity

Alexander V. Chervonsky

Treg Cells, Life History, and Diversity Christophe Benoist and Diane Mathis

Infectious (Non)tolerance--Frustrated

Commensalism Gone Awry? Jesse C. Nussbaum and Richard M. Locksley

Historical Overview of Immunological Tolerance Ronald H. Schwartz

Natural Killer Cell Tolerance: Control by Self or

Self-Control?

Baptiste N. Jaeger and Eric Vivier

For additional articles in this collection, see http://cshperspectives.cshlp.org/cgi/collection/

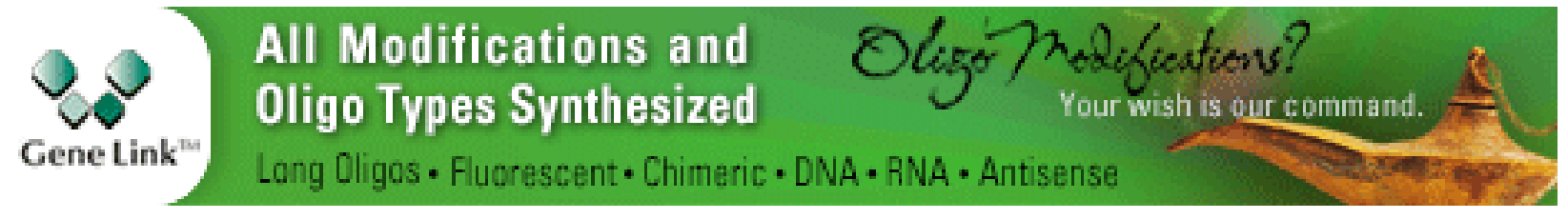

Copyright (C 2012 Cold Spring Harbor Laboratory Press; all rights reserved 